\title{
Synthesis, spectral characterization and in vitro microbiological evaluation of novel glyoxal, biacetyl and benzil bis-hydrazone macrocyclic Schiff bases and their $\mathrm{Co}(\mathrm{II}), \mathrm{Ni}(\mathrm{II})$ and $\mathrm{Cu}(\mathrm{II})$ complexes
}

\author{
B. Lakshmi a , Prakash Gouda Avaji ${ }^{\text {b,* }}$, K.N. Shivananda ${ }^{a}$, Praveen Nagella ${ }^{\text {c }, ~ S . H . ~ M a n o h a r ~}{ }^{\text {c }}$, K.N. Mahendra ${ }^{\mathrm{a}, *}$ \\ a Department of Chemistry, Bangalore University, Bangalore 560 001, Karnataka, India \\ ${ }^{\mathrm{b}}$ Department of Chemistry, Karnataka University, Dharwad 580 003, Karnataka, India \\ c Department of Botany, Karnataka University, Dharwad 580 003, Karnataka, India
}

\section{A R T I C L E I N F O}

Article history:

Received 22 November 2010

Accepted 1 March 2011

Available online 16 March 2011

Keywords:

Synthesis

Characterization

Bis-hydrazone

Biological

\begin{abstract}
A B S T R A C T
A series of binuclear $\mathrm{Co}(\mathrm{II}), \mathrm{Ni}(\mathrm{II})$ and $\mathrm{Cu}(\mathrm{II})$ complexes were synthesized by the template condensation of glyoxal, biacetyl or benzil bis-hydrazide, 2,6-diformyl-4-methylphenol and $\mathrm{Co}$ (II), $\mathrm{Ni}$ (II) or $\mathrm{Cu}$ (II) chloride in a 2:2:2 $\mathrm{M}$ ratio in ethanol. These 22-membered macrocyclic complexes were characterized by elemental analyses, magnetic, molar conductance, spectral, thermal and fluorescence studies. Elemental analyses suggest the complexes have a $2: 1$ stoichiometry of the type $\left[\mathrm{M}_{2} \mathrm{LX}_{2}\right] \cdot n \mathrm{H}_{2} \mathrm{O}$ and $\left[\mathrm{Ni}_{2} \mathrm{LX}_{2} 2 \mathrm{H}_{2} \mathrm{O}\right] \cdot n \mathrm{H}_{2} \mathrm{O}$ (where $\mathrm{M}=\mathrm{Co}(\mathrm{II})$ and $\mathrm{Cu}(\mathrm{II}) ; \mathrm{L}=\mathrm{H}_{2} \mathrm{~L}^{1}, \mathrm{H}_{2} \mathrm{~L}^{2}$ and $\mathrm{H}_{2} \mathrm{~L}^{3} ; \mathrm{X}=\mathrm{Cl} ; n=2$ ). From the spectroscopic and magnetic studies, it has been concluded that the $\mathrm{Co}$ (II) and $\mathrm{Cu}$ (II) complexes display a five coordinated square pyramidal geometry and the $\mathrm{Ni}$ (II) complexes have a six coordinated octahedral geometry. The Schiff bases and their metal complexes have also been screened for their antibacterial and antifungal activities by the MIC method.
\end{abstract}

(c) 2011 Elsevier Ltd. All rights reserved.

\section{Introduction}

Metal complexes of macrocyclic Schiff bases derived from 2,6-diformyl-4-methylphenol have great interest as potential compartmental ligands capable of forming mono and binuclear coordination compounds with various metals because of several donor centers in their molecules [1-10]. Currently, there is a growing interest in the design and synthesis of bis-hydrazones along with their metal complexes because of their applications as anticancer, antiviral, antibacterial and antifungal agents [11-13]. Our research has continued on bis-hydrazones with glyoxal, biacetyl and benzil with 2,6-diformyl-4-methylphenol. Many binuclear metal complexes have been studied extensively as phenoxo bridged acyclic and macrocyclic complexes of 2,6-diformyl-4-methylphenol, which have specific electric, magnetic, optical and catalytic properties [12,14-24].

A previous study has reported that the C2-symmetric dialkylamino substructure in glyoxal bis-hydrazones is the key design element resulting in the successful application of these compounds as novel N-ligands for the enantioselective copper(II)-catalyzed dielsalder cycloaddition reaction [25]. Bifunctional bis(thiosemicarba-

* Corresponding authors. Present address: Department of Organic Chemistry, Indian Institute of Science, Bangalore 560 012, India (P.G. Avaji). Tel.: +91 802293 2406; fax: +91802360 0529 .

E-mail address: apg.iisc@gmail.com (P.G. Avaji). zone) ligands with arylcarboxylates appended at the exocyclic nitrogens have been developed and characterized by X-ray crystallography [26]. Very recently oxido-bridged copper benzoate, bis-hydroxido-bridged copper azide and copper thiocyanate complexes have been synthesized with 2,6-bis(benzyliminomethyl)4-methylphenol. These complexes have been characterized by $\mathrm{X}$-ray crystallography and their magnetic properties have been studied [19].

As a part of our continuing efforts to explore multidentate Schiff-base ligands for the building blocks of new supramolecular assemblies, we describe here the synthesis and spectral investigation of phenoxo-bridged binuclear $\mathrm{Co}(\mathrm{II}), \mathrm{Ni}(\mathrm{II})$ and $\mathrm{Cu}(\mathrm{II})$ transition metal ions with 2,6-diformyl-4-methylphenol and glyoxal, biacetyl and benzil bis-hydrazone Schiff bases. A survey of the literature reveal that no work has been carried out on the above mentioned metal complexes. These Schiff bases have donor sites with the NON NON sequence and varied coordination abilities. This nature of the Schiff bases (Scheme 1) have attracted our attention and aroused our interest in elucidating the structures of $\mathrm{Co}(\mathrm{II})$, $\mathrm{Ni}(\mathrm{II})$ and $\mathrm{Cu}(\mathrm{II})$ complexes. These complexes are evaluated for their antibacterial and antifungal properties against various pathogenic bacteria (Escherichia coli, Staphylococcus aureus, Shigella dysentry, Micrococcus, Bacillus subtilis, Bacillus cereus and Pseudomonas aeruginosa) and fungal strains (Aspergillus niger, Penicillium and Candida albicans) using the minimum inhibitory concentration (MIC) method. 


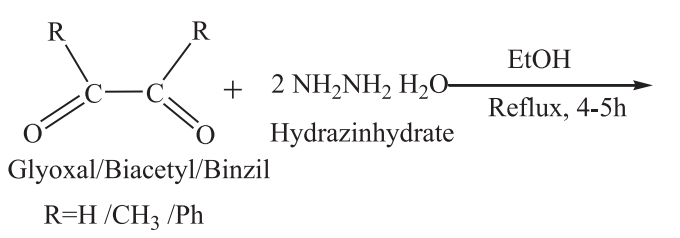<smiles>[R]C(=NN)C([R])=NN</smiles>

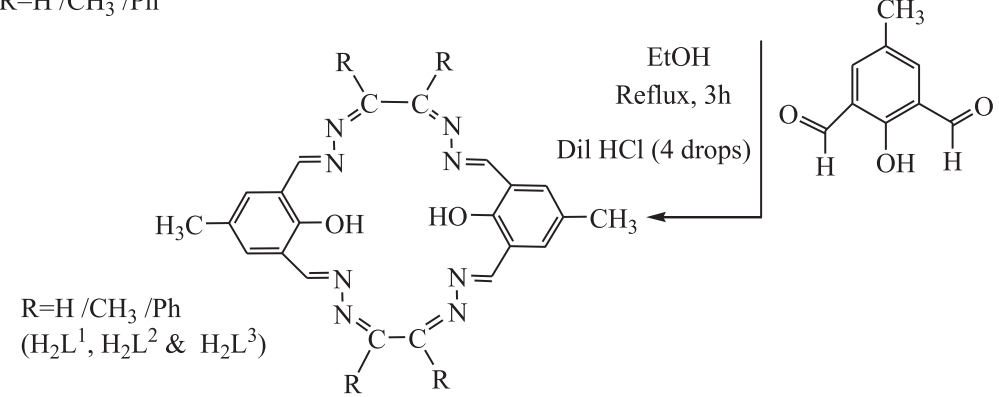

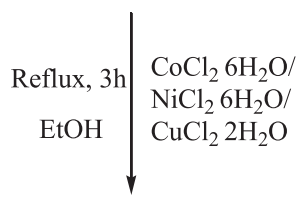
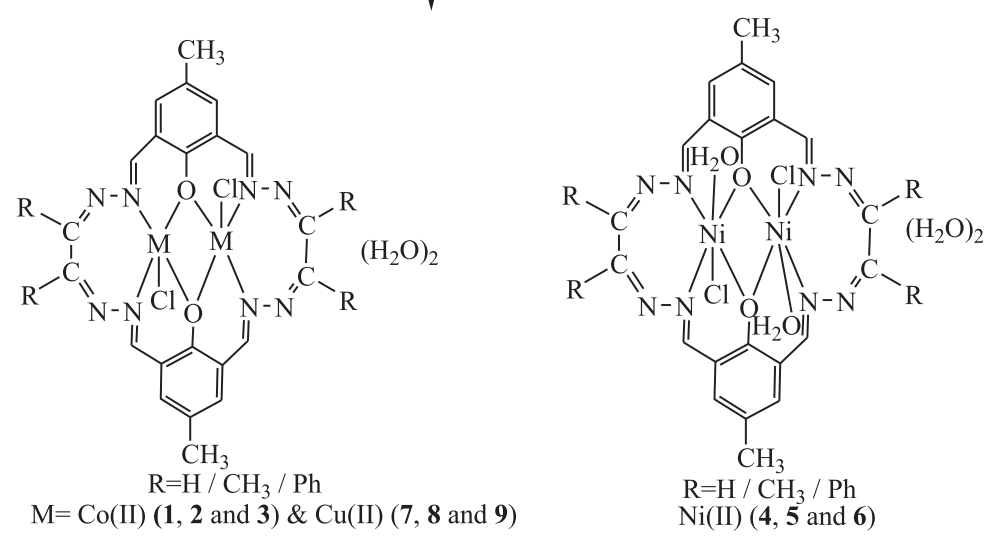

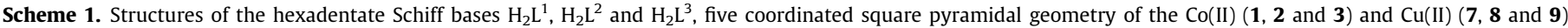
complexes and six coordinated octahedral geometry of the $\operatorname{Ni}(\mathrm{II})(\mathbf{4}, \mathbf{5}$ and $\mathbf{6})$ complexes.

\section{Experimental}

\subsection{Physical measurements}

The IR spectra of the Schiff base ligands and their $\mathrm{Co}(\mathrm{II}), \mathrm{Ni}(\mathrm{II})$ and $\mathrm{Cu}(\mathrm{II})$ complexes were recorded on a HITACHI-270 IR spectrophotometer in the $4000-250 \mathrm{~cm}^{-1}$ region as $\mathrm{KBr}$ disks. The electronic spectra of the complexes were recorded in DMF on a VARIAN CARY 50-BIO UV-spectrophotometer in the region 200$1100 \mathrm{~nm}$. The ${ }^{1} \mathrm{H}$ NMR spectra of the Schiff bases were recorded in $\mathrm{CDCl}_{3}$ on a BRUKER $300 \mathrm{MHz}$ spectrometer at room temperature using TMS as an internal reference. FAB mass spectra were recorded on a JEOL SX 102/DA-6000 mass spectrometer/data system using Argon/Xenon $(6 \mathrm{kV}, 10 \mathrm{Am})$ as the FAB gas. The accelerating voltage was $10 \mathrm{kV}$ and the spectra were recorded at room temperature, and $m$-nitrobenzyl alcohol was used as the matrix. The mass spectrometer was operated in the positive ion mode. Molar conductivity measurements were recorded on an ELICO-CM-82T conductivity bridge with a cell having a cell constant of 0.51 , and magnetic moments were measured with a faraday balance. Thermogravimetric analysis data were measured from room temperature to $1000^{\circ} \mathrm{C}$ at a heating rate of $10^{\circ} \mathrm{C} / \mathrm{min}$. The data were obtained using a PERKIN-ELMER DIAMOND TG/ DTG instrument.

\subsection{Chemical and reagents}

All chemicals used were of reagent grade. Solvents were distilled and dried before use according to standard procedures [27]. The remaining reagents were purchased from Ranbaxy chemicals and were used without further purification.

\subsection{Analyses}

The $\mathrm{Co}(\mathrm{II}), \mathrm{Ni}(\mathrm{II})$ and $\mathrm{Cu}(\mathrm{II})$ complexes were analyzed by a gravimetric method [28]. The results of elemental analyses ( $\mathrm{C}, \mathrm{H}$ and $\mathrm{N}$ ), magnetic and molar conductance values agree well with the predicted structures.

\subsection{Methods}

2.4.1. Synthesis of the dihydrazides of glyoxal, biacetyl and benzyl

A mixture of glyoxal, biacetyl or benzil $(0.1 \mathrm{~mol})$ and hydrazine hydrate $(2 \mathrm{cc}$ ) in ethanol was refluxed for $4-5 \mathrm{~h}$. The reaction mixture was allowed to cool to room temperature, then the cooled solution was poured onto ice cold water. The dihydrazide of glyoxal, biacetyl or benzil thus obtained was filtered and recrystallized from ethanol and then dried in a vacuum over $\mathrm{P}_{2} \mathrm{O}_{5}$. Yield: $80 \%$. 


\subsubsection{Preparation of 2,6-diformyl-4-methylphenol}

2,6-Diformyl-4-methylphenol was prepared according to the reported method $[29,30]$. Note, skin contact with 2,6-diformyl-4methylphenol causes persistent deep yellow stains.

\subsubsection{Synthesis of glyoxal, biacetyl and benzil bis-hydrazone Schiff} bases $\left(\mathrm{H}_{2} \mathrm{~L}^{1}, \mathrm{H}_{2} \mathrm{~L}^{2}\right.$ and $\left.\mathrm{H}_{2} \mathrm{~L}^{3}\right)$

A mixture of glyoxal, biacetyl or benzil bis-hydrazide and 2,6diformyl-4-methylphenol in 2:2 M proportions in an alcoholic medium containing a few drops of concentrated $\mathrm{HCl}$ were refluxed for 3-4 h. The product separated on evaporation of the alcohol and was recrystallized from ethanol. Yield: $75 \%$.

\subsubsection{Synthesis of $\left[\mathrm{M}_{2} L X_{2}\right] \cdot n \mathrm{H}_{2} \mathrm{O}$ and $\left[\mathrm{Ni}_{2} \mathrm{LX}_{2} 2 \mathrm{H}_{2} \mathrm{O}\right] \cdot n \mathrm{H}_{2} \mathrm{O}$ (where} $M=\mathrm{Co}(\mathrm{II})$ and $\mathrm{Cu}(\mathrm{II}) ; \mathrm{L}=\mathrm{H}_{2} L^{1}, \mathrm{H}_{2} L^{2}$ and $\left.\mathrm{H}_{2} L^{3} ; X=\mathrm{Cl} ; n=2\right)$ complexes

To a hot solution of 2,6-diformyl-4-methylphenol $(0.02 \mathrm{~mol})$ in ethanol $(20 \mathrm{ml})$, crystalline glyoxal, biacetyl or benzil bis-hydrazide $(0.02 \mathrm{~mol})$ was added, followed by the drop-wise addition of the metal salt $\left(\mathrm{CoCl}_{2} \cdot 6 \mathrm{H}_{2} \mathrm{O} / \mathrm{NiCl}_{2} \cdot 6 \mathrm{H}_{2} \mathrm{O} / \mathrm{CuCl}_{2} \cdot 2 \mathrm{H}_{2} \mathrm{O}\right.$; $(0.02 \mathrm{~mol})$ in ethanol solution with constant stirring. The reaction mixture was refluxed for about an hour, then $2 \mathrm{~g}$ of sodium acetate $(0.02 \mathrm{~mol})$ in water was added and refluxing was continued for about $3 \mathrm{~h}$. The metal(II) complex that separated was filtered and washed free of reagents with distilled water containing small quantity of ethanol, and then it was dried in a vacuum over fused $\mathrm{CaCl}_{2}$.

\section{Pharmacology}

\subsection{In vitro antibacterial and antifungal assay}

The biological activities of the newly synthesized Schiff bases $\left(\mathrm{H}_{2} \mathrm{~L}^{1}, \mathrm{H}_{2} \mathrm{~L}^{2}\right.$ and $\left.\mathrm{H}_{2} \mathrm{~L}^{3}\right)$ and their $\mathrm{Co}(\mathrm{II}), \mathrm{Ni}(\mathrm{II})$ and $\mathrm{Cu}(\mathrm{II})$ metal complexes have been studied for their antibacterial and antifungal activities by the disk diffusion method [31,32]. The antibacterial activities were recorded for the following organisms: E. coli, S. aureus, S. dysentry, Micrococcus species, B. subtilis, B. cereus and $P$. aeruginosa. These bacterial strains were chosen as they are known pathogens of the human body, and A. niger, Penicillium species and $C$. albicans were used for antifungal activities at 10, 25, 50 and $100 \mu \mathrm{g} / \mathrm{mL}$ concentrations in the solvent DMF, where a DMF poured disk was used as a negative control. The bacteria were subcultured in agar medium. The petri dishes were incubated for $24 \mathrm{~h}$ at $37^{\circ} \mathrm{C}$. A standard antibacterial drug (Gentamycine) was also screened under similar conditions for comparison. The fungi were subcultured in potato dextrose agar medium. A standard antifungal drug (Fluconazole) was used for comparison. The petri dishes were incubated for $48 \mathrm{~h}$ at $37^{\circ} \mathrm{C}$ (Figs. 1 and 2).

\subsubsection{Minimum inhibitory concentration (MIC)}

Compounds showing promising antibacterial/antifungal activity were selected for minimum inhibitory concentration studies.

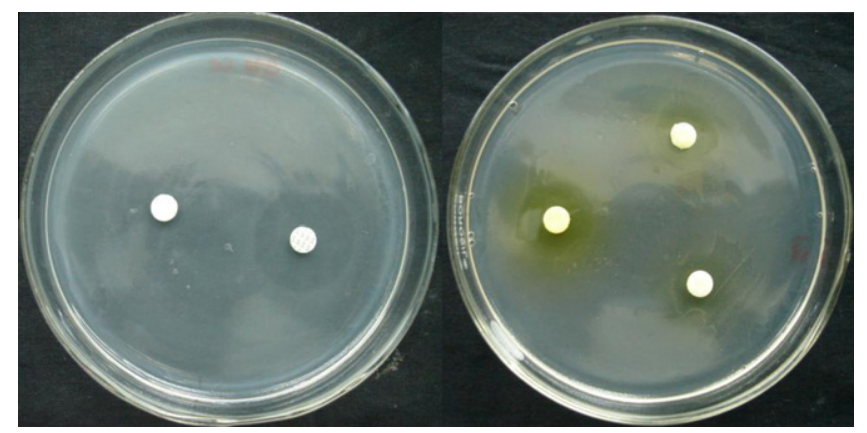

Fig. 1. Photograph showing the antibacterial (E. coli) screening of gentamycine and the $\mathrm{Ni}(\mathrm{II})$ complex (5).

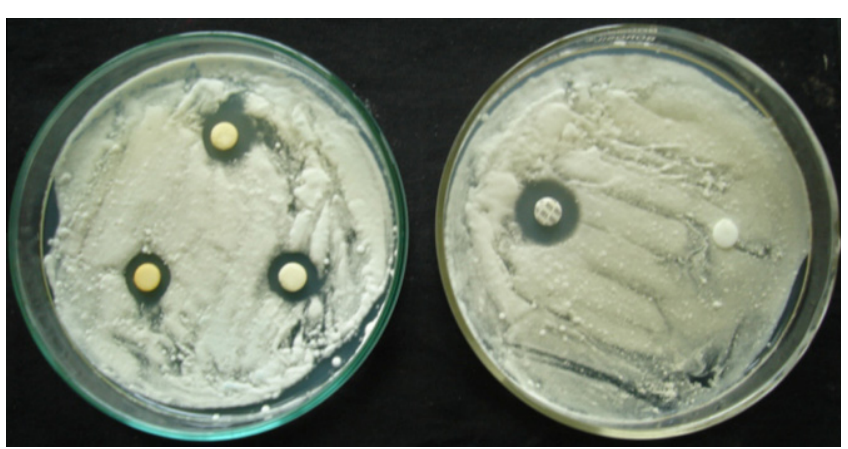

Fig. 2. Photograph showing the antifungal (Candida albicana) screening of the Schiff base $\mathrm{H}_{2} \mathrm{~L}^{2}$ and flucanazole.

The MIC is the lowest concentration of an antibacterial compound that will inhibit the visible growth of microorganisms after $24 \mathrm{~h}$ incubation, and the minimum inhibitory concentrations are important in diagnostic laboratories to confirm the resistance of microorganisms to antimicrobial agents. The synthesized compounds were screened against bacterial and fungal strains through a macrodilution tube method [33]. The minimum inhibitory concentration was determined by assaying at 100,50 and $25 \mu \mathrm{g} \mathrm{ml}^{-1}$ concentrations, along with standards at the same concentrations.

\section{Results and discussion}

The spectral and analytical data show the formula of the $\mathrm{Co}(\mathrm{II})$, $\mathrm{Ni}(\mathrm{II})$ and $\mathrm{Cu}(\mathrm{II})$ complexes as $\left[\mathrm{M}_{2} \mathrm{LX}_{2}\right] \cdot n \mathrm{H}_{2} \mathrm{O}$ and $\left[\mathrm{Ni}_{2} \mathrm{LX}_{2} 2-\right.$ $\mathrm{H}_{2} \mathrm{O}$ ] $n \mathrm{H}_{2} \mathrm{O}$ (where $\mathrm{M}=\mathrm{Co}(\mathrm{II})$ and $\mathrm{Cu}\left(\mathrm{II}\right.$ ); $\mathrm{L}=\mathrm{H}_{2} \mathrm{~L}^{1}, \mathrm{H}_{2} \mathrm{~L}^{2}$ and $\mathrm{H}_{2} \mathrm{~L}^{3}$; $\mathrm{X}=\mathrm{Cl} ; n=2)$. All the $\mathrm{Co}(\mathrm{II}), \mathrm{Ni}(\mathrm{II})$ and $\mathrm{Cu}(\mathrm{II})$ complexes are colored, stable in air and non-hygroscopic solids. They are sparingly soluble in common organic solvents; however, these complexes are soluble in DMF and DMSO. The elemental analyses show that the Co(II), $\mathrm{Ni}(\mathrm{II})$ and $\mathrm{Cu}(\mathrm{II})$ complexes have a 2:1 stoichiometry of the type $\mathrm{M}_{2}$ : L. The molar conductance values at $10^{-3} \mathrm{M}$ concentration are too low to account for any dissociation of the complexes in DMF. Hence, the $\mathrm{Co}(\mathrm{II}), \mathrm{Ni}(\mathrm{II})$ and $\mathrm{Cu}(\mathrm{II})$ complexes may be regarded as non-electrolytes. In order to establish whether the water molecules present in the complexes coordinated to the metal ion, weighed complexes were dried in over $\mathrm{P}_{2} \mathrm{O}_{5}$ in vacuum desiccators for $1 \mathrm{~h}$ and then weighed again. No loss in weight was observed. These observations suggest that the water molecules in the complexes are coordinated to the metal ion. The spectroscopic and magnetic studies conclude a five coordinated square pyramidal geometry for the $\mathrm{Co}(\mathrm{II})$ and $\mathrm{Cu}(\mathrm{II})$ complexes and a six coordinated octahedral geometry for the $\mathrm{Ni}(\mathrm{II})$ complexes. The elemental analytical data of the Schiff bases and their $\mathrm{Co}(\mathrm{II}), \mathrm{Ni}(\mathrm{II})$ and $\mathrm{Cu}(\mathrm{II})$ complexes are listed in Tables 1 and 2 respectively.

\subsection{Infrared spectra}

The important IR frequencies of the Schiff bases and their $\mathrm{Co}(\mathrm{II})$, $\mathrm{Ni}(\mathrm{II})$ and $\mathrm{Cu}(\mathrm{II})$ complexes are presented in Tables 3 and 4 . In order to study the binding mode of the Schiff base to the metal ion in the complexes, the IR spectrum of the free Schiff base was compared with the spectra of the transition metal complexes. A strong band is observed for the free Schiff bases at around $1630 \mathrm{~cm}^{-1}$, characteristic of the azomethine $(\mathrm{C}=\mathrm{N})$ stretching vibrations. In the metal chelates, the band characteristic of the azomethine group is shifted to $1610-1590 \mathrm{~cm}^{-1}$ from $1630 \mathrm{~cm}^{-1}$ in the ligand, suggesting coordination of the azomethine nitrogen atom to the metal ion [34,35]. In addition to this, a medium intensity broad band observed at around $3100 \mathrm{~cm}^{-1}$ in the Schiff bases is due to 
Table 1

Analytical data of Schiff bases $\mathrm{H}_{2} \mathrm{~L}^{1}, \mathrm{H}_{2} \mathrm{~L}^{2}$ and $\mathrm{H}_{2} \mathrm{~L}^{3}$.

\begin{tabular}{|c|c|c|c|c|c|c|c|c|}
\hline \multirow[t]{2}{*}{ Comp. No. } & \multirow[t]{2}{*}{ Empirical formula } & \multicolumn{2}{|l|}{$\mathrm{C} \%$} & \multicolumn{2}{|l|}{$\mathrm{H} \%$} & \multicolumn{2}{|l|}{$\mathrm{N} \%$} & \multirow[t]{2}{*}{ Yield (\%) } \\
\hline & & Obsd. & Calcd. & Obsd. & Calcd. & Obsd. & Calcd. & \\
\hline $\mathrm{H}_{2} \mathrm{~L}^{1}$ & $\left(\mathrm{C}_{22} \mathrm{H}_{20} \mathrm{~N}_{6} \mathrm{O}_{2}\right)$ & 61.57 & 61.68 & 4.75 & 4.67 & 19.56 & 19.62 & 64 \\
\hline $\mathrm{H}_{2} \mathrm{~L}^{2}$ & $\left(\mathrm{C}_{26} \mathrm{H}_{28} \mathrm{~N}_{6} \mathrm{O}_{2}\right)$ & 64.41 & 64.46 & 5.69 & 5.78 & 17.28 & 17.35 & 67 \\
\hline $\mathrm{H}_{2} \mathrm{~L}^{3}$ & $\left(\mathrm{C}_{46} \mathrm{H}_{36} \mathrm{~N}_{6} \mathrm{O}_{2}\right)$ & 75.36 & 75.4 & 4.85 & 4.91 & 11.41 & 11.47 & 70 \\
\hline
\end{tabular}

Table 2

Elemental analysis, magnetic and molar conductance data of the $\mathrm{Co}(\mathrm{II}), \mathrm{Ni}(\mathrm{II})$ and $\mathrm{Cu}(\mathrm{II})$ complexes of the $\mathrm{Schiff}$ bases $\mathrm{H}_{2} \mathrm{~L}^{1}, \mathrm{H}_{2} \mathrm{~L}^{2}$ and $\mathrm{H}_{2} \mathrm{~L}^{3}$.

\begin{tabular}{|c|c|c|c|c|c|c|c|c|c|}
\hline \multirow[t]{2}{*}{ Comp.No. } & \multirow[t]{2}{*}{ Empirical formula } & \multicolumn{2}{|l|}{$\mathrm{M} \%$} & \multicolumn{2}{|l|}{$\mathrm{N} \%$} & \multicolumn{2}{|l|}{$\mathrm{Cl} \%$} & \multirow[t]{2}{*}{$\lambda_{\mathrm{m}}\left(\mathrm{cm}^{2} \Omega^{-1} \mathrm{~mol}^{-1}\right)$} & \multirow[t]{2}{*}{$\mu_{\mathrm{eff}}(\mathrm{BM})$} \\
\hline & & Obsd. & Calcd. & Obsd. & Calcd. & Obsd. & Calcd. & & \\
\hline 1 & {$\left[\mathrm{Co}_{2}\left(\mathrm{H}_{2} \mathrm{~L}^{1}\right) \mathrm{Cl}_{2}\right] \cdot 2 \mathrm{H}_{2} \mathrm{O}$} & 18.12 & 18.15 & 17.18 & 17.23 & 10.72 & 10.76 & 22.16 & 4.23 \\
\hline 2 & {$\left[\mathrm{Co}_{2}\left(\mathrm{H}_{2} \mathrm{~L}^{2}\right) \mathrm{Cl}_{2}\right] \cdot 2 \mathrm{H}_{2} \mathrm{O}$} & 16.65 & 16.71 & 15.79 & 15.86 & 9.87 & 9.91 & 21.87 & 4.42 \\
\hline 3 & {$\left[\mathrm{Co}_{2}\left(\mathrm{H}_{2} \mathrm{~L}^{3}\right) \mathrm{Cl}_{2}\right] \cdot 2 \mathrm{H}_{2} \mathrm{O}$} & 12.30 & 12.36 & 11.68 & 11.74 & 7.25 & 7.33 & 20.65 & 4.84 \\
\hline 4 & {$\left[\mathrm{Ni}_{2}\left(\mathrm{H}_{2} \mathrm{~L}^{1}\right) \mathrm{Cl}_{2}\left(\mathrm{H}_{2} \mathrm{O}\right)_{2}\right] \cdot 2 \mathrm{H}_{2} \mathrm{O}$} & 16.89 & 16.95 & 16.31 & 16.37 & 10.18 & 10.23 & 24.57 & 2.52 \\
\hline 5 & {$\left[\mathrm{Ni}_{2}\left(\mathrm{H}_{2} \mathrm{~L}^{2}\right) \mathrm{Cl}_{2}\left(\mathrm{H}_{2} \mathrm{O}\right)_{2}\right] \cdot 2 \mathrm{H}_{2} \mathrm{O}$} & 15.61 & 15.67 & 15.09 & 15.13 & 9.37 & 9.45 & 25.32 & 3.24 \\
\hline 6 & {$\left[\mathrm{Ni}_{2}\left(\mathrm{H}_{2} \mathrm{~L}^{3}\right) \mathrm{Cl}_{2}\left(\mathrm{H}_{2} \mathrm{O}\right)_{2}\right] \cdot 2 \mathrm{H}_{2} \mathrm{O}$} & 11.68 & 11.74 & 11.25 & 11.33 & 6.92 & 7.08 & 26.54 & 3.53 \\
\hline 7 & {$\left[\mathrm{Cu}_{2}\left(\mathrm{H}_{2} \mathrm{~L}^{1}\right) \mathrm{Cl}_{2}\right] \cdot 2 \mathrm{H}_{2} \mathrm{O}$} & 19.11 & 19.17 & 16.96 & 17.04 & 10.61 & 10.65 & 23.32 & 1.42 \\
\hline 8 & {$\left[\mathrm{Cu}_{2}\left(\mathrm{H}_{2} \mathrm{~L}^{2}\right) \mathrm{Cl}_{2}\right] \cdot 2 \mathrm{H}_{2} \mathrm{O}$} & 17.58 & 17.64 & 15.59 & 15.68 & 9.78 & 9.80 & 22.76 & 1.40 \\
\hline 9 & {$\left[\mathrm{Co}_{2}\left(\mathrm{H}_{2} \mathrm{~L}^{3}\right) \mathrm{Cl}_{2}\right] \cdot 2 \mathrm{H}_{2} \mathrm{O}$} & 13.01 & 13.09 & 11.61 & 11.64 & 7.21 & 7.27 & 21.14 & 1.45 \\
\hline
\end{tabular}

Table 3

The important infrared frequencies (in $\mathrm{cm}^{-1}$ ) of the Schiff bases $\mathrm{H}_{2} \mathrm{~L}^{1}, \mathrm{H}_{2} \mathrm{~L}^{2}$ and $\mathrm{H}_{2} \mathrm{~L}^{3}$.

\begin{tabular}{lllll}
\hline Ligand No. & $v(\mathrm{C}=\mathrm{N})$ & H-bonded-OH & $v_{\mathrm{CH}_{3}}$ & Phenolic C-O \\
\hline $\mathrm{H}_{2} \mathrm{~L}^{1}$ & 1624 & 2744 & 2932 & 1291 \\
$\mathrm{H}_{2} \mathrm{~L}^{2}$ & 1626 & 2735 & 2927 & 1283 \\
$\mathrm{H}_{2} \mathrm{~L}^{3}$ & 1630 & 2726 & 2932 & 1285 \\
$\mathrm{H}_{2} \mathrm{~L}^{4}$ & 1620 & 2741 & 2924 & 1294 \\
\hline
\end{tabular}

$v(\mathrm{NH})$. A high intensity band is present in the $1295-1285 \mathrm{~cm}^{-1}$ region, with an additional band around $1500 \mathrm{~cm}^{-1}$, which were assigned to phenolic $v(\mathrm{C}-\mathrm{O})$ vibrations $[35,36]$.

In the Schiff bases it is generally observed that an intramolecular $\mathrm{H}$-bonded-OH band occurs in the region $2700-2600 \mathrm{~cm}^{-1}$ as a broad weak band with fine structure [37]. These bands are missing in the metal complexes indicating that the phenol character of the ligand has been lost upon complexation. The bands present in the range $3010-3050 \mathrm{~cm}^{-1}$ may be assigned to $v(\mathrm{C}-\mathrm{H})$ stretching vibrations of benzil. The various absorption bands in the region $1450-1588 \mathrm{~cm}^{-1}$ may be assigned to $\mathrm{v}(\mathrm{C}=\mathrm{C})$ aromatic stretching vibrations of the benzil ring. The bands in the region 740$785 \mathrm{~cm}^{-1}$ may be assigned to $n(\mathrm{C}-\mathrm{H})$ out of plane bending of the aromatic rings.

The presence of broad stretching vibrations in the 3440$3400 \mathrm{~cm}^{-1}$ region can be attributed to coordinated or lattice water molecules in all these complexes [38]. Broad bands in the regions $550-400,474-400$ and $340 \mathrm{~cm}^{-1}$ are assigned to $v(\mathrm{M}-\mathrm{O}), v(\mathrm{M}-\mathrm{N})$ and $v(\mathrm{M}-\mathrm{Cl})$ vibrations respectively [39-44].

\section{2. ${ }^{1} \mathrm{H}$ NMR spectra}

The ${ }^{1} \mathrm{H}$ NMR spectra of the Schiff bases $\mathrm{H}_{2} \mathrm{~L}^{1}, \mathrm{H}_{2} \mathrm{~L}^{2}$ and $\mathrm{H}_{2} \mathrm{~L}^{3}$ exhibited a signal at $11.5 \mathrm{ppm}$ due to the azomethine protons. The spectra of the ligands show the $-\mathrm{N}-\mathrm{H} \cdots \mathrm{O}$ resonance at $13.72 \mathrm{ppm}[45,46]$. We also observed a multiplet at 7.5-7.8 ppm due to aromatic protons. All the compounds exhibited a signal at $10.50 \mathrm{ppm}$ due to the phenolic $\mathrm{OH}$ proton. The compounds exhibited a signal at $2.5 \mathrm{ppm}$ due to methyl protons. All these observations provide support for the IR inferences.

\subsection{Electronic absorption spectra}

The electronic absorption spectra of the $\mathrm{Co}(\mathrm{II}), \mathrm{Ni}(\mathrm{II})$ and $\mathrm{Cu}(\mathrm{II})$ complexes have been studied with a view to obtain more information on the configuration of the complexes. The electronic spectra of the $\mathrm{Co}(\mathrm{II})$ complexes exhibit absorption bands in the regions 10965,17134 and $19972 \mathrm{~cm}^{-1}$, which can be assigned to the transitions ${ }^{4} \mathrm{~A}_{2}+{ }^{4} \mathrm{E} \rightarrow{ }^{4} \mathrm{~B}_{1},{ }^{4} \mathrm{~A}_{2}+{ }^{4} \mathrm{E} \rightarrow{ }^{4} \mathrm{E}(\mathrm{P})$ and ${ }^{4} \mathrm{~A}_{2}+{ }^{4} \mathrm{E} \rightarrow{ }^{4} \mathrm{~A}_{2}(\mathrm{P})$ respectively and are characteristic of a square pyramidal geometry [47]. The $\mathrm{Ni}(\mathrm{II})$ complexes shown three bands at 10992,15259 and $21968 \mathrm{~cm}^{-1}$ which are assigned to ${ }^{3} \mathrm{~A}_{2 \mathrm{~g}}(\mathrm{~F}) \rightarrow{ }^{3} \mathrm{~T}_{2 \mathrm{~g}}(\mathrm{~F})\left(v_{1}\right)$, ${ }^{3} \mathrm{~A}_{2 \mathrm{~g}}(\mathrm{~F}) \rightarrow{ }^{3} \mathrm{~T}_{1 \mathrm{~g}}(\mathrm{~F})\left(v_{2}\right)$ and ${ }^{3} \mathrm{~A}_{2 \mathrm{~g}}(\mathrm{~F}) \rightarrow{ }^{3} \mathrm{~T}_{1 \mathrm{~g}}(\mathrm{P})\left(v_{3}\right)$ transitions respectively, indicating an octahedral geometry [47]. The $\mathrm{Cu}(\mathrm{II})$ complexes exhibited a high intensity band at $27468 \mathrm{~cm}^{-1}$ in the UV-region. The appearance of this band is due to a $\pi \rightarrow \pi^{*}$ transition associated with the azomethine linkage and a $\mathrm{L} \rightarrow \mathrm{M}$ charge transfer transition. The electronic spectra of the $\mathrm{Cu}$ (II) complexes also show three bands at 10972,14828 and $23156 \mathrm{~cm}^{-1}$, and

Table 4

The important infrared frequencies (in $\mathrm{cm}^{-1}$ ) of the $\mathrm{Co}$ (II), Ni(II) and $\mathrm{Cu}$ (II) complexes of the Schiff bases $\mathrm{H}_{2} \mathrm{~L}^{1}, \mathrm{H}_{2} \mathrm{~L}^{2}$ and $\mathrm{H}_{2} \mathrm{~L}^{3}$.

\begin{tabular}{|c|c|c|c|c|c|c|c|}
\hline Complex No. & $v(\mathrm{OH})$ & $v(\mathrm{C}=\mathrm{N})$ & $v_{\mathrm{CH}_{3}}$ & Phenolic C-O & $v(\mathrm{M}-\mathrm{N})$ & $v(\mathrm{M}-\mathrm{O})$ & $v(\mathrm{M}-\mathrm{Cl})$ \\
\hline 1 & 3430 & 1607 & 2926 & 1548 & 464 & 535 & 325 \\
\hline 2 & 3425 & 1590 & 2918 & 1550 & 470 & 525 & 330 \\
\hline 3 & 3436 & 1608 & 2922 & 1535 & 435 & 536 & 326 \\
\hline 4 & 3440 & 1612 & 2930 & 1538 & 422 & 550 & 335 \\
\hline 5 & 3421 & 1603 & 2915 & 1542 & 448 & 533 & 322 \\
\hline 6 & 3434 & 1595 & 2921 & 1536 & 436 & 521 & 331 \\
\hline 7 & 3426 & 1608 & 2930 & 1542 & 454 & 540 & 324 \\
\hline 8 & 3438 & 1593 & 2917 & 1544 & 435 & 532 & 340 \\
\hline 9 & 3434 & 1591 & 2930 & 1550 & 463 & 545 & 328 \\
\hline
\end{tabular}


these bands have been assigned to the transition ${ }^{2} \mathrm{~B}_{1} \rightarrow{ }^{2} \mathrm{~A}_{1}(v 1)$, ${ }^{2} \mathrm{~B}_{1} \rightarrow{ }^{2} \mathrm{~B}_{2}\left(v_{2}\right)$ and ${ }^{2} \mathrm{~B}_{1} \rightarrow{ }^{2} \mathrm{E}\left(v_{3}\right)$ respectively. These transitions are characteristic of a square pyramidal geometry $[47,48]$.

\subsection{Magnetic studies}

The magnetic moments of the $\mathrm{Co}(\mathrm{II}), \mathrm{Ni}(\mathrm{II})$ and $\mathrm{Cu}(\mathrm{II})$ complexes were obtained at room temperature. The $\mathrm{Co}(\mathrm{II})(\mathbf{1 - 3})$ and $\mathrm{Ni}(\mathrm{II})(\mathbf{4 -}$ 6) complexes shown magnetic moment values of around 4.23-4.84 and 2.52-3.53 BM respectively, which are lower than the respective spin only values and indicate weak antiferromagnetic coupling interactions between the metal ions, further confirming the dinuclear nature of the complexes. The $\mathrm{Cu}$ (II) complexes showed a magnetic moment value of around $1.45 \mathrm{MB}$, which is considerably lower than the spin only value. The low value of the magnetic moment is attributed to an antiferromagnetic coupling interaction between two metal ions. This fact suggests the dinuclear nature of the $\mathrm{Cu}(\mathrm{II})$ complexes [49].

\subsection{FAB mass spectra of the Schiff base $\mathrm{H}_{2} \mathrm{~L}^{1}$ and its $\mathrm{Cu}(\mathrm{II})$ complex (7)}

The FAB spectrum of the Schiff base $\mathrm{H}_{2} \mathrm{~L}^{1}$ showed a molecular ion peak at $m / z 773$ (Fig. 3) which is equivalent to its molecular weight. The fragments in the spectrum lead to the formation of the species $\left[\mathrm{C}_{46} \mathrm{H}_{36} \mathrm{~N}_{8} \mathrm{O}_{2}\right]^{+}$. The $\mathrm{FAB}$ mass spectrum of the $\mathrm{Cu}(\mathrm{II})$ complex of the ligand $\mathrm{H}_{2} \mathrm{~L}^{1}$ (7) showed a molecular ion peak $\mathrm{M}^{+}$ at $m / z 963$, which is equivalent to the molecular weight of the $\mathrm{Cu}$ (II) complex (7) shown in Fig. 4. The molecular ion peak at $\mathrm{m} / \mathrm{z}$ 926 is due to the loss of two water molecules.

\subsection{ESR spectrum of $\mathrm{Cu}(\mathrm{II})$ complex (7)}

The X-band ESR spectrum of the $\mathrm{Cu}(\mathrm{II})$ complex with the ligand $\mathrm{H}_{2} \mathrm{~L}^{1}$ (7) was recorded at room temperature using DPPH as a reference standard. The $g_{\|}$and $g_{\perp}$ values have been found to be 2.089 and 2.024 respectively. In general, dinuclear $\mathrm{Cu}(\mathrm{II})$ complexes give broad ESR peaks and the broadening is assigned to a dipolar inter-
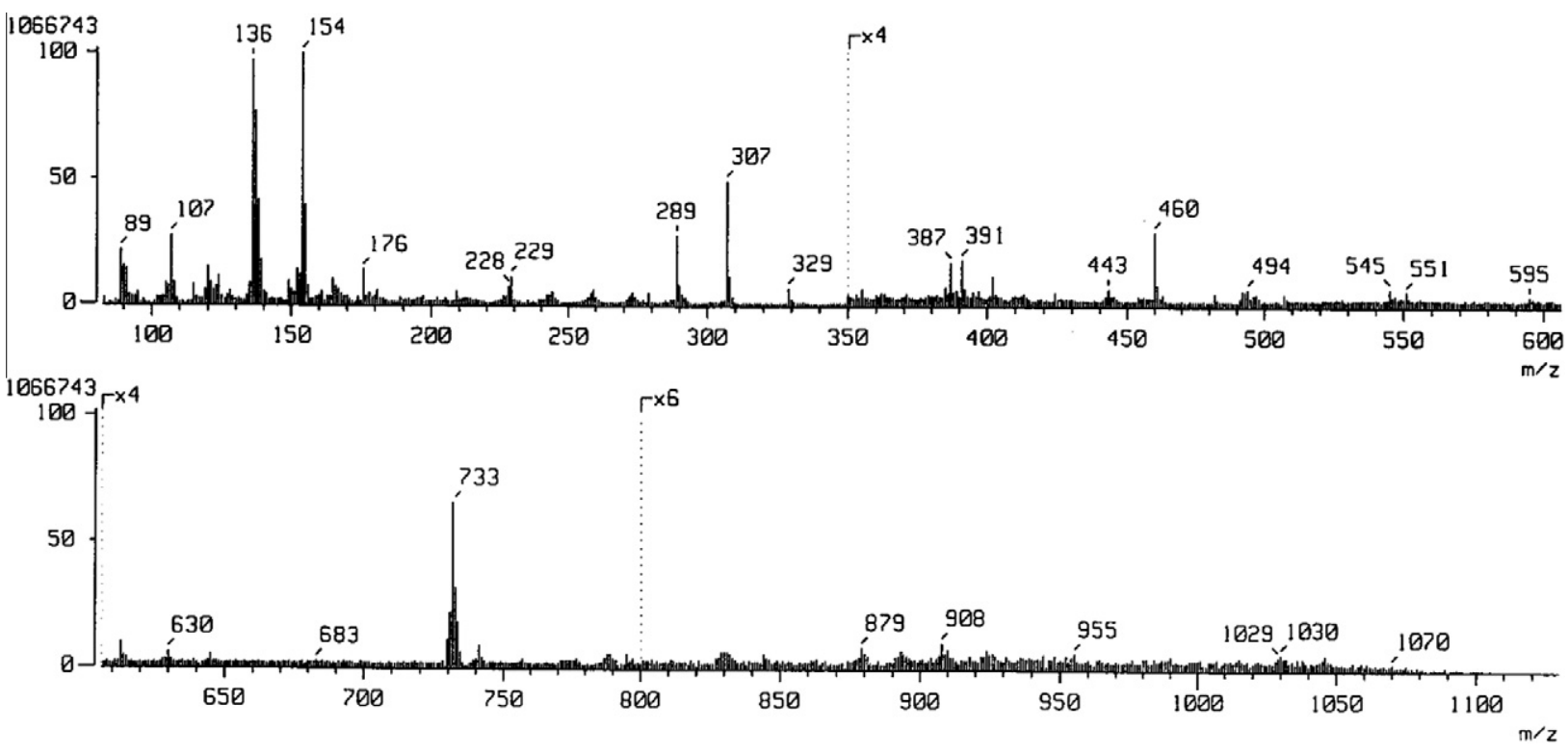

Fig. 3. FAB-mass spectrum of the Schiff base $\mathrm{H}_{2} \mathrm{~L}^{1}$.
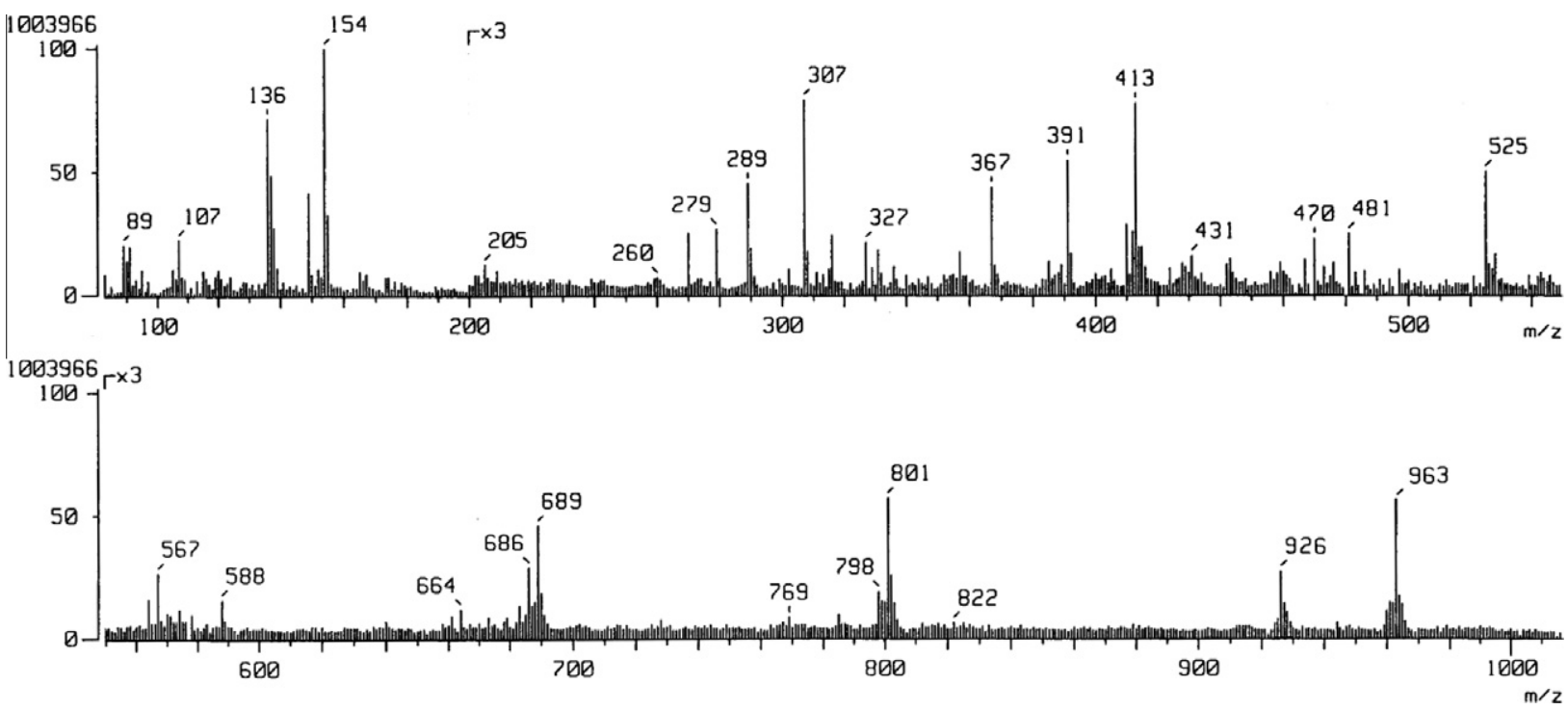

Fig. 4. FAB-mass spectrum of the $\mathrm{Cu}(\mathrm{II})$ complex (7). 


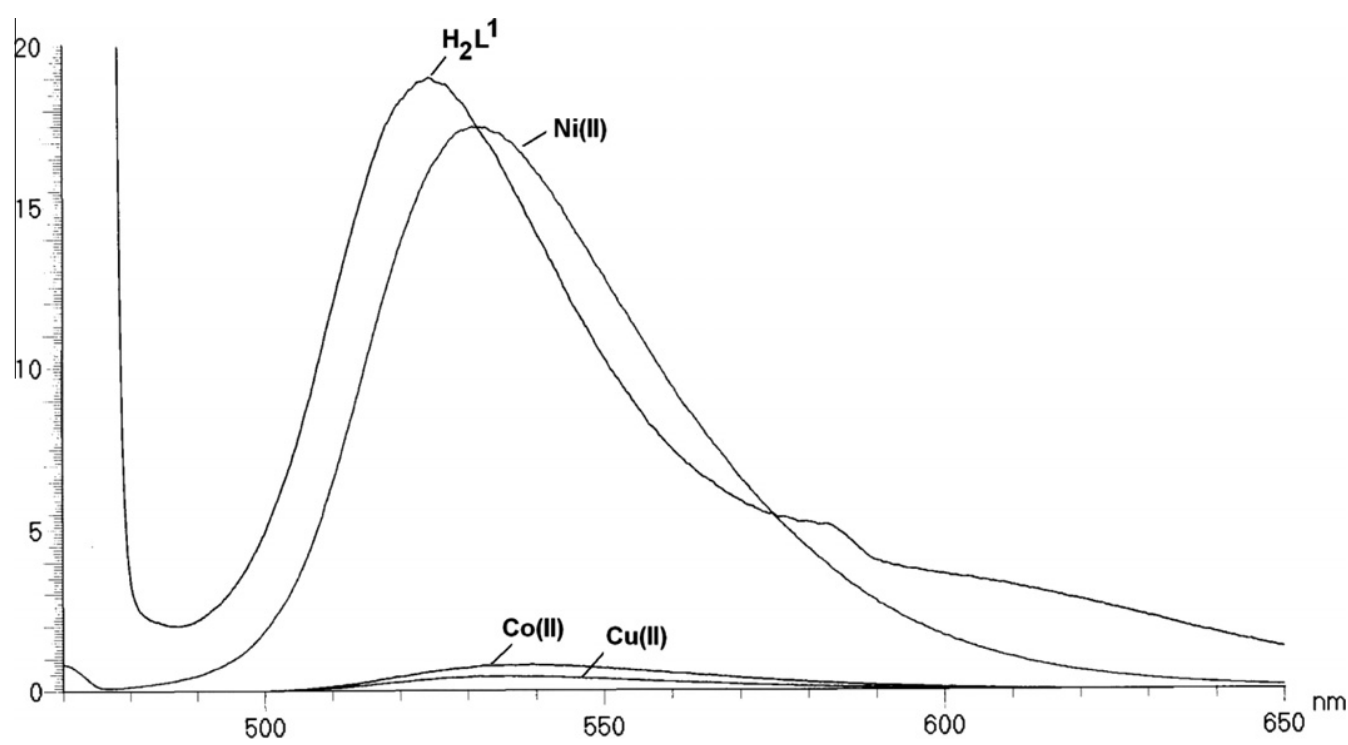

Fig. 5. Emission spectra of the Schiff base $\mathrm{H}_{2} \mathrm{~L}^{1}$ and its $\mathrm{Co}(\mathrm{II})(\mathbf{1}), \mathrm{Ni}(\mathrm{II})(\mathbf{4})$ and $\mathrm{Cu}(\mathrm{II})(\mathbf{7})$ complexes in DMSO.

Table 5

Thermogravimetric data of the $\mathrm{Co}(\mathrm{II})(\mathbf{2}), \mathrm{Ni}(\mathrm{II})(\mathbf{5})$ and $\mathrm{Cu}(\mathrm{II})(\mathbf{8})$ complexes of the Schiff base $\mathrm{H}_{2} \mathrm{~L}^{2}$.

\begin{tabular}{|c|c|c|c|c|c|}
\hline \multirow[t]{2}{*}{ Comp. No. } & \multirow[t]{2}{*}{ Empirical formula } & \multirow{2}{*}{$\begin{array}{l}\text { Decomposition } \\
\text { temperature }\left({ }^{\circ} \mathrm{C}\right)\end{array}$} & \multicolumn{2}{|c|}{$\%$ Weight loss } & \multirow[t]{2}{*}{ Inference } \\
\hline & & & Obsd. & Calcd. & \\
\hline \multirow[t]{3}{*}{2} & \multirow[t]{3}{*}[\mathrm{Co}_{2}(\mathrm{H}_{2}\mathrm{L}^{2})\mathrm{Cl}_{2}]{$\cdot 2 \mathrm{H}_{2} \mathrm{O}$} & $125-130$ & 5.02 & 5.09 & Loss of water molecules \\
\hline & & $242-253$ & 44.96 & 45.08 & Loss of aldehyde moieties \\
\hline & & $315-332$ & 31.12 & 31.16 & Loss of bishydrazone moieties \\
\hline \multirow[t]{3}{*}{5} & \multirow[t]{3}{*}[\mathrm{Ni}_{2}(\mathrm{H}_{2}\mathrm{L}^{2})\mathrm{Cl}_{2}(\mathrm{H}_{2}\mathrm{O})_{2}]{$\cdot 2 \mathrm{H}_{2} \mathrm{O}$} & $115-139$ & 4.78 & 4.86 & Loss of coordinated water molecules \\
\hline & & $250-265$ & 42.91 & 42.97 & Loss of one aldehyde moieties \\
\hline & & $342-362$ & 29.69 & 29.72 & Loss of one bishydrazone moieties \\
\hline \multirow[t]{3}{*}{8} & \multirow[t]{3}{*}[\mathrm{Cu}_{2}(\mathrm{H}_{2}\mathrm{L}^{2})\mathrm{Cl}_{2}]{$\cdot 2 \mathrm{H}_{2} \mathrm{O}$} & $110-120$ & 4.98 & 5.04 & Loss of water molecules \\
\hline & & $237-240$ & 44.48 & 44.53 & Loss of aldehyde moieties \\
\hline & & $310-320$ & 30.76 & 30.81 & Loss of bishydrazone moieties \\
\hline
\end{tabular}

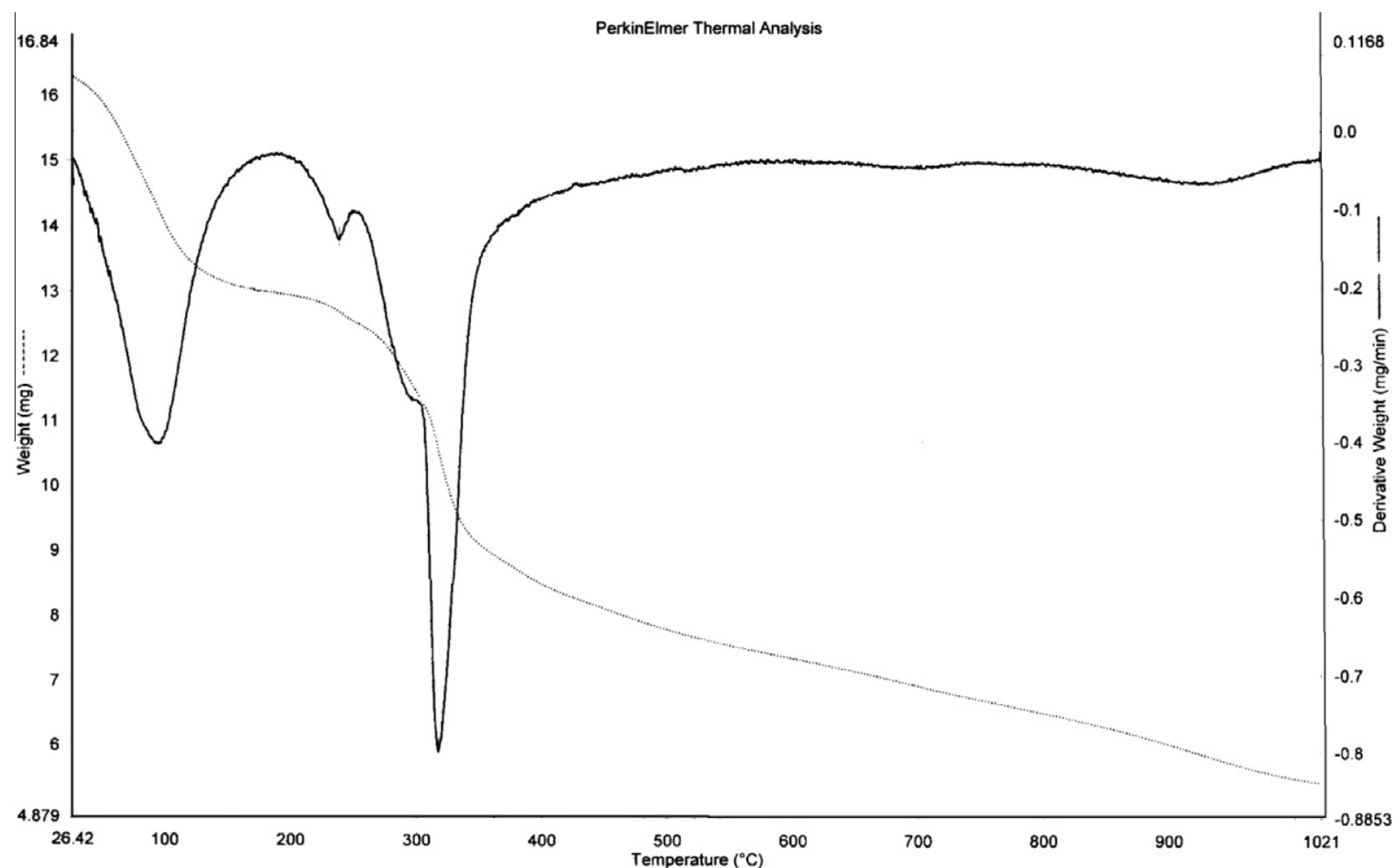

Fig. 6. Thermogravimetric (TG/DTG) curves of the Ni(II) complex (5). 
Table 6

Selected bond lengths $(\AA)$ and bond angles $\left({ }^{\circ}\right)$ of the $\mathrm{Cu}(\mathrm{II})$ complex (7).

\begin{tabular}{|c|c|c|c|}
\hline $\begin{array}{l}\text { Compound } \\
\text { No. (7) }\end{array}$ & $\begin{array}{l}\text { Bond lengths } \\
(\AA)\end{array}$ & Compound No. (7) & $\begin{array}{l}\text { Bond angles } \\
\left({ }^{\circ}\right)\end{array}$ \\
\hline$C(7)-N(29)$ & 1.49161 & $C(5)-C(7)-N(29)$ & 128.048 \\
\hline $\mathrm{C}(16)-\mathrm{N}(28)$ & 1.29690 & $\mathrm{C}(7)-\mathrm{N}(29)-\mathrm{N}(8)$ & 113.210 \\
\hline $\mathrm{C}(6)-\mathrm{N}(27)$ & 1.29697 & $\mathrm{~N}(8)-\mathrm{C}(10)-\mathrm{C}(12)$ & 131.831 \\
\hline $\mathrm{C}(17)-\mathrm{N}(26)$ & 1.29928 & $C(10)-C(12)-N(15)$ & 132.921 \\
\hline $\mathrm{N}(29)-\mathrm{N}(8)$ & 1.41698 & $\mathrm{C}(12)-\mathrm{N}(15)-\mathrm{N}(28)$ & 119.985 \\
\hline $\mathrm{N}(28)-\mathrm{N}(15)$ & 1.38493 & $\mathrm{~N}(15)-\mathrm{N}(28)-\mathrm{C}(16)$ & 112.392 \\
\hline $\mathrm{N}(26)-\mathrm{N}(9)$ & 1.39200 & $\mathrm{~N}(28)-\mathrm{C}(16)-\mathrm{C}(20)$ & 126.759 \\
\hline $\mathrm{N}(27)-\mathrm{N}(14)$ & 1.38492 & $C(16)-C(20)-C(23)$ & 117.650 \\
\hline $\mathrm{N}(8)-\mathrm{C}(10)$ & 1.27944 & $C(20)-C(23)-C(19)$ & 122.922 \\
\hline $\mathrm{N}(15)-\mathrm{C}(12)$ & 1.28119 & $C(23)-C(19)-C(22)$ & 116.572 \\
\hline$N(9)-C(11)$ & 1.27945 & $C(19)-C(22)-C(21)$ & 122.878 \\
\hline$N(14)-C(13)$ & 1.28118 & $C(22)-C(21)-C(18)$ & 119.632 \\
\hline$C(1)-C(5)$ & 1.42629 & $C(21)-C(18)-C(20)$ & 117.188 \\
\hline$C(5)-C(7)$ & 1.43919 & $C(18)-C(20)-C(23)$ & 119.732 \\
\hline$C(10)-C(12)$ & 1.47903 & $C(16)-C(20)-C(18)$ & 121.877 \\
\hline$C(16)-C(20)$ & 1.44424 & $C(20)-C(18)-C(21)$ & 117.188 \\
\hline$C(20)-C(18)$ & 1.42803 & $C(18)-C(21)-C(17)$ & 123.019 \\
\hline$C(18)-C(21)$ & 1.42631 & $C(22)-C(21)-C(17)$ & 116.960 \\
\hline$C(21)-C(17)$ & 1.43912 & $C(26)-C(17)-C(21)$ & 128.095 \\
\hline$C(11)-C(13)$ & 1.47898 & $\mathrm{C}(17)-\mathrm{N}(26)-\mathrm{N}(9)$ & 113.182 \\
\hline$C(6)-C(4)$ & 1.44417 & $\mathrm{~N}(26)-\mathrm{N}(9)-\mathrm{C}(11)$ & 119.472 \\
\hline$C(4)-C(1)$ & 1.42801 & $\mathrm{~N}(9)-\mathrm{C}(11)-\mathrm{C}(13)$ & 131.862 \\
\hline$C(4)-C(3)$ & 1.40288 & $\mathrm{C}(13)-\mathrm{N}(14)-\mathrm{N}(27)$ & 119.991 \\
\hline$C(4)-C(45)$ & 1.39687 & $\mathrm{~N}(27)-\mathrm{C}(6)-\mathrm{C}(4)$ & 126.750 \\
\hline$C(45)-C(2)$ & 1.39250 & $C(4)-C(1)-C(5)$ & 117.190 \\
\hline$C(2)-C(5)$ & 1.40858 & $\mathrm{Cu}(30)-\mathrm{O}(24)-\mathrm{Cu}(31)$ & 106.289 \\
\hline$C(45)-C(46)$ & 1.50974 & $\mathrm{O}(24)-\mathrm{Cu}(31)-\mathrm{O}(25)$ & 73.727 \\
\hline$C(20)-C(23)$ & 1.40287 & $\mathrm{Cu}(31)-\mathrm{O}(25)-\mathrm{Cu}(30)$ & 106.278 \\
\hline$C(23)-C(19)$ & 1.39690 & $\mathrm{O}(25)-\mathrm{Cu}(30)-\mathrm{O}(24)$ & 73.707 \\
\hline$C(19)-C(22)$ & 1.39245 & $\mathrm{~N}(29)-\mathrm{Cu}(31)-\mathrm{O}(28)$ & 96.538 \\
\hline$C(22)-C(21)$ & 1.40861 & & \\
\hline$C(19)-C(47)$ & 1.50973 & & \\
\hline $\mathrm{C}(1)-\mathrm{O}(24)$ & 1.30740 & & \\
\hline $\mathrm{C}(18)-\mathrm{O}(25)$ & 1.30739 & & \\
\hline $\mathrm{O}(24)-\mathrm{Cu}(13)$ & 2.02873 & & \\
\hline $\mathrm{O}(25)-\mathrm{Cu}(31)$ & 1.96210 & & \\
\hline $\mathrm{O}(25)-\mathrm{Cu}(30)$ & 2.02933 & & \\
\hline $\mathrm{O}(24)-\mathrm{Cu}(30)$ & 1.96242 & & \\
\hline $\mathrm{Cl}(32)-\mathrm{Cu}(30)$ & 2.34122 & & \\
\hline $\mathrm{Cl}(33)-\mathrm{Cu}(31)$ & 2.34039 & & \\
\hline $\mathrm{N}(29)-\mathrm{Cu}(31)$ & 1.75416 & & \\
\hline $\mathrm{N}(28)-\mathrm{Cu}(31)$ & 2.09015 & & \\
\hline $\mathrm{N}(26)-\mathrm{Cu}(30)$ & 1.93543 & & \\
\hline $\mathrm{N}(27)-\mathrm{Cu}(30)$ & 2.08855 & & \\
\hline
\end{tabular}

action [50]. The observed ESR spectrum is characteristic of a square pyramidal geometry. The $g_{\text {av }}$ value was calculated to be 2.046 . The existence of $g_{\|}>g_{\perp}$ suggests that the $d_{x^{2}-y^{2}}$ orbital is in the ground state and the $d^{9}$ configuration is $\left(e_{g}\right)^{4}\left(a_{1 g}\right)^{2}\left(b_{2 g}\right)^{2}\left(b_{1 g}\right)^{1}$. The $g$ values are related to the axial symmetry and $g_{\|}>g_{\perp}$ suggests a square pyramidal geometry of the $\mathrm{Cu}(\mathrm{II})$ complex. The axial symmetry parameter $G=3.70$, which being less than 4.0 indicates a considerable exchange interaction between the metal ions in the solid complex, which further supports the dinuclear nature of the $\mathrm{Cu}$ (II) complexes.

\subsection{Fluorescence studies}

The emission spectrum of the Schiff base $\mathrm{H}_{2} \mathrm{~L}^{1}$ and its $\mathrm{Co}(\mathrm{II})(\mathbf{1})$, $\mathrm{Ni}(\mathrm{II})$ (4) and $\mathrm{Cu}$ (II) (7) complexes were investigated in various solvents, viz., DMF, DMSO, MeCN and THF. The Schiff base $\mathrm{H}_{2} \mathrm{~L}^{1}$ shows a weak absorption band at $524 \mathrm{~nm}$, Fig. 5, which is due to the 2,6diformyl-4-methylphenolate ion. The $\mathrm{Co}(\mathrm{II})(\mathbf{1}), \mathrm{Ni}(\mathrm{II})(\mathbf{4})$ and $\mathrm{Cu}$ (II) (7) complexes were characterized by an emission band at around $535 \mathrm{~nm}$ in DMF and DMSO, and it is also observed that the emission band of the Schiff base, at around $524 \mathrm{~nm}$, was blue shifted in the $\mathrm{Co}(\mathrm{II})$ (1), $\mathrm{Ni}(\mathrm{II})$ (4) and $\mathrm{Cu}(\mathrm{II})$ (7) complexes due to the interaction of the phenolic oxygen with the metal ions (Fig. 5). We also observed a fluorescence quenching interaction in the above mentioned complexes in DMF and DMSO solutions.

\subsection{Thermal studies}

TG and DTG studies were carried out for the $\mathrm{Co}(\mathrm{II})(\mathbf{2}), \mathrm{Ni}(\mathrm{II})$ (5) and $\mathrm{Cu}(\mathrm{II})(\mathbf{8})$ complexes. These complexes decomposed gradually with the formation of the respective metal oxide above $400{ }^{\circ} \mathrm{C}$. The nature of the proposed chemical change with temperature range and the percentage loss of compounds obtained are given in Table 5. The thermal decomposition of the $\mathrm{Co}(\mathrm{II})(\mathbf{2}), \mathrm{Ni}(\mathrm{II})(\mathbf{5})$ and $\mathrm{Cu}(\mathrm{II})$ (8) complexes occurs in three steps, as indicated by DTG peaks corresponding to the mass loss of coordinated water molecules, aldehyde moieties and bis-hydrazone moieties respectively (Fig. 6).

\subsection{Molecular modeling}

In the absence of a crystal structure, to obtain the molecular conformation of a complex energy minimization studies were carried out. These studies were performed using GAUSSIAN 09 software. Optimization was performed using the B3LYP/6-31+G* basis set in the gas phase along with frequency to obtain a global minimum of the $\mathrm{Cu}(\mathrm{II})$ (7) complex as a representative example. The metal-ligand bond lengths and bond angles are given in Table 6 .

\subsection{Pharmacology results}

The microbial results of the Schiff bases and their $\mathrm{Co}(\mathrm{II}), \mathrm{Ni}(\mathrm{II})$ and $\mathrm{Cu}(\mathrm{II})$ complexes are recorded in Table 7 . The biological activ-

Table 7

Bacteriological results of the Schiff bases $\mathrm{H}_{2} \mathrm{~L}^{1}, \mathrm{H}_{2} \mathrm{~L}^{2}$ and $\mathrm{H}_{2} \mathrm{~L}^{3}$ and their $\mathrm{Co}(\mathrm{II}), \mathrm{Ni}(\mathrm{II})$ and $\mathrm{Cu}(\mathrm{II})$ complexes at a concentration of $25 \mu \mathrm{g}$ ml ${ }^{-1}$.

\begin{tabular}{|c|c|c|c|c|c|c|c|c|c|c|}
\hline \multirow[t]{2}{*}{ Empirical formula } & \multicolumn{7}{|c|}{ Activity against bacteria $(\mathrm{mm})$} & \multicolumn{3}{|c|}{ Activity against fungi (mm) } \\
\hline & E. coli & P. aeruginosa & B. cereus & S. aureus & S. dysentry & Micrococcus & B. subtilis & A. niger & Penicillium & C. albicans \\
\hline$\left(\mathrm{C}_{22} \mathrm{H}_{20} \mathrm{~N}_{6} \mathrm{O}_{2}\right)$ & 08 & 10 & 12 & 14 & 08 & 08 & 06 & 14 & 10 & 12 \\
\hline$\left(\mathrm{C}_{26} \mathrm{H}_{28} \mathrm{~N}_{6} \mathrm{O}_{2}\right)$ & 10 & 12 & 16 & 12 & 12 & 10 & 08 & 16 & 14 & 14 \\
\hline$\left(\mathrm{C}_{46} \mathrm{H}_{36} \mathrm{~N}_{6} \mathrm{O}_{2}\right)$ & 12 & 10 & 14 & 12 & 10 & 12 & 08 & 14 & 12 & 12 \\
\hline$\left[\mathrm{Co}_{2}\left(\mathrm{H}_{2} \mathrm{~L}^{1}\right) \mathrm{Cl}_{2}\right] \cdot 2 \mathrm{H}_{2} \mathrm{O}$ & 08 & 12 & 10 & 14 & 10 & 10 & 10 & 14 & 12 & 10 \\
\hline$\left[\mathrm{Co}_{2}\left(\mathrm{H}_{2} \mathrm{~L}^{2}\right) \mathrm{Cl}_{2}\right] \cdot 2 \mathrm{H}_{2} \mathrm{O}$ & 12 & 16 & 14 & 14 & 12 & 12 & 08 & 16 & 12 & 12 \\
\hline$\left[\mathrm{Co}_{2}\left(\mathrm{H}_{2} \mathrm{~L}^{3}\right) \mathrm{Cl}_{2}\right] \cdot 2 \mathrm{H}_{2} \mathrm{O}$ & 10 & 14 & 12 & 12 & 12 & 10 & 10 & 12 & 10 & 10 \\
\hline$\left[\mathrm{Ni}_{2}\left(\mathrm{H}_{2} \mathrm{~L}^{1}\right) \mathrm{Cl}_{2}\left(\mathrm{H}_{2} \mathrm{O}\right)_{2}\right] \cdot 2 \mathrm{H}_{2} \mathrm{O}$ & 10 & 10 & 10 & 10 & 08 & 08 & 06 & 14 & 12 & 14 \\
\hline$\left[\mathrm{Ni}_{2}\left(\mathrm{H}_{2} \mathrm{~L}^{2}\right) \mathrm{Cl}_{2}\left(\mathrm{H}_{2} \mathrm{O}\right)_{2}\right] \cdot 2 \mathrm{H}_{2} \mathrm{O}$ & 14 & 12 & 12 & 12 & 10 & 10 & 10 & 16 & 10 & 10 \\
\hline$\left[\mathrm{Ni}_{2}\left(\mathrm{H}_{2} \mathrm{~L}^{3}\right) \mathrm{Cl}_{2}\left(\mathrm{H}_{2} \mathrm{O}\right)_{2}\right] \cdot 2 \mathrm{H}_{2} \mathrm{O}$ & 12 & 10 & 14 & 14 & 08 & 12 & 08 & 14 & 12 & 14 \\
\hline$\left[\mathrm{Cu}_{2}\left(\mathrm{H}_{2} \mathrm{~L}^{1}\right) \mathrm{Cl}_{2}\right] \cdot 2 \mathrm{H}_{2} \mathrm{O}$ & 12 & 12 & 10 & 12 & 12 & 10 & 10 & 14 & 12 & 12 \\
\hline$\left[\mathrm{Cu}_{2}\left(\mathrm{H}_{2} \mathrm{~L}^{2}\right) \mathrm{Cl}_{2}\right] \cdot 2 \mathrm{H}_{2} \mathrm{O}$ & 14 & 14 & 12 & 14 & 10 & 08 & 12 & 16 & 10 & 12 \\
\hline$\left[\mathrm{Co}_{2}\left(\mathrm{H}_{2} \mathrm{~L}^{3}\right) \mathrm{Cl}_{2}\right] \cdot 2 \mathrm{H}_{2} \mathrm{O}$ & 12 & 10 & 14 & 10 & 12 & 12 & 10 & 12 & 10 & 10 \\
\hline Gentamycine & 20 & 20 & 20 & 20 & 20 & 20 & 20 & - & - & - \\
\hline Flucanazole & - & - & - & - & - & - & - & 24 & 24 & 24 \\
\hline DMF & 12 & 12 & 12 & 12 & 12 & 12 & 12 & 12 & 12 & 12 \\
\hline
\end{tabular}



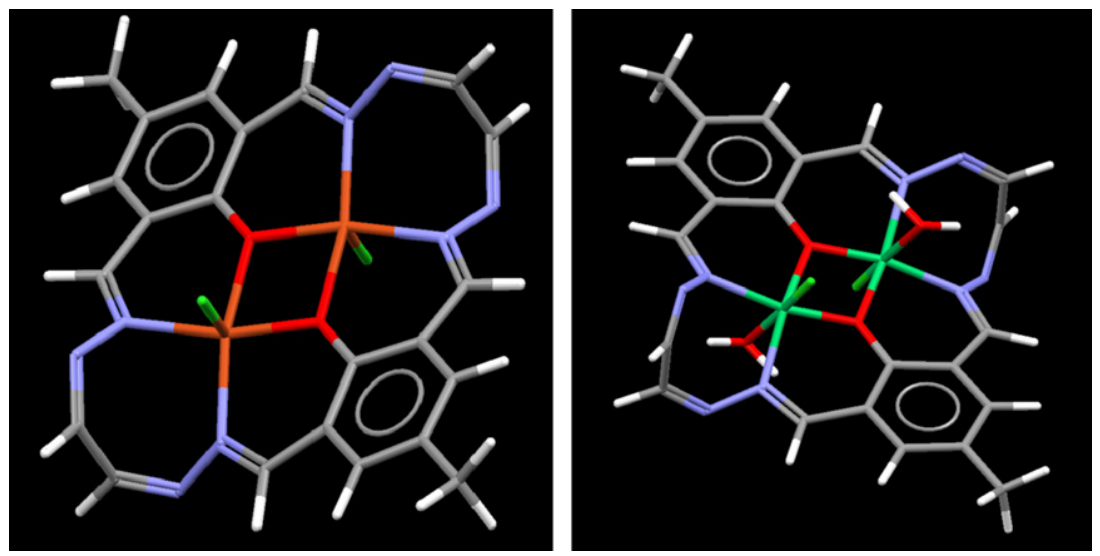

Fig. 7. Spartan minimized structures of the $\mathrm{Cu}(\mathrm{II})(\mathbf{7})$ and $\mathrm{Ni}(\mathrm{II})(\mathbf{4})$ complexes.

ity of the Schiff bases exhibited a considerable enhancement on coordination with the metal ions against all fungal strains, and the metal complexes showed good antifungal activity against $\mathrm{A}$. $\mathrm{ni}$ ger, Penicillium species and $C$. albicans. It was evident from the data that this activity significantly increased on coordination. This enhancement in the activity may be rationalized on the basis that their structures mainly possess an additional $\mathrm{C}=\mathrm{N}$ bond. It has been suggested that Schiff bases with nitrogen and oxygen donor systems inhibit enzyme activity since the enzymes which require these groups for their activity appear to be especially more susceptible to deactivation by metal ions on coordination. Moreover, coordination reduces the polarity $[51,52]$ of the metal ion, mainly because of the partial sharing of its positive charge with the donor groups $[53,54]$ within the chelate ring system formed during coordination. This process, in turn, increases the lipophilic nature of the central metal atom, which favors its permeation more efficiently through the lipid layer of the microorganism [55-57], thus destroying them more aggressively.

Some important factors, such as the nature of the metal ion, nature of the ligand, coordinating sites, geometry of the complex, concentration, hydrophilicity, lipophilicity and presence of co-ligands, have considerable influence on the antibacterial activity. Certainly, steric and pharmacokinetic factors also play a decisive role in deciding the potency of an antimicrobial agent. Apart from this, the mode of action of these compounds may also invoke hydrogen bonds through the $>\mathrm{C}=\mathrm{N}-\mathrm{N}=\mathrm{CH}$ - group with the active centers and thus interfere with the normal cell process. The presence of lipophilic and polar substituents is expected to enhance antibacterial activity. Bis-hydrazone ligands with multifunctionality have a greater chance of interaction either with nucleoside bases (even after complexation with metal ions) or with biologically essential metal ions present in the biosystem, and can be promising candidates as bactericides since they always tend to interact, especially with some enzymatic functional groups, in order to achieve higher coordination numbers [58].

\section{Conclusion}

The synthesized 22-membered macrocyclic glyoxal, biacetyl and benzil bis-hydrazone Schiff bases act as hexadentate ligands. The metal ion is coordinated through the azomethine nitrogen and phenolic oxygen atoms in all the Schiff bases. The bonding of the ligands to the metal ion was confirmed by the analytical, IR, NMR, ESR, electronic, magnetic, FAB mass and thermal data. All compounds are insoluble in water but soluble in DMF and DMSO solvents, and decompose at high temperatures. All these observations put together lead us to propose the following structures shown in Fig. 7 (Scheme 1). Schiff bases and their $\mathrm{Co}(\mathrm{II}), \mathrm{Ni}(\mathrm{II})$ and $\mathrm{Cu}(\mathrm{II})$ complexes were found to be potentially active towards microbial strains.

\section{References}

[1] F. Hueso-Urena, J. Inorg. Biochem. 94 (2003) 326.

[2] A.J. Atkins, D. Black, R.L. Finn, A. Marin-Becerra, A.J. Blake, L. Ruiz-Ramirez, W.S Li, M. Schroder, J. Chem. Soc., Dalton Trans. (2003) 1730-1737.

[3] M.J. MacLachlan, M.K. Park, L.K. Thompson, Inorg. Chem. 35 (1996) 5492.

[4] B.F. Hoskins, G.A. Williams, Aust. J. Chem. 28 (1975) 2607.

[5] B.F. Hoskins, N.J. McLeod, H.A. Schaap, Aust. J. Chem. 29 (1976) 515.

[6] C.L. Spiro, S.L. Lambert, T.J. Smith, E.N. Duesler, R.R. Gagng, D.N. Hendrickson, Inorg. Chem. 20 (1981) 1229.

[7] Y.P. Tupolova, L.D. Popov, V.V. Lukov, I.N. Shcherbakov, S.I. Levchenkov, V.A Kogan, O.V. Maevskiy, V.G. Vlasenko, A.A. Zubenko, J. Inorg. Gen. Chem. 635 (2009) 530.

[8] N.H. Pilkington, R. Robson, Aust. J. Chem. 23 (1970) 2225.

[9] H. Okawa, M. Tadokoro, Y. Aratake, M. Ohba, K. Shindo, M. Mitsumi, M Kiokawa, M. Tomono, D.E. Fenton, J. Chem. Soc., Dalton. Trans. (1993) 253-258.

[10] H. Okawa, J. Nishio, M. Ohba, M. Tadokoro, N. Matsumoto, M. Koikawa, S. Kida, D.E. Fenton, Inorg. Chem. 32 (1993) 2949.

[11] A.S. Pedrares, N. Camina, J. Romero, M.L. Duran, J.G. kVazquez, A. Sousa Polyhedron 27 (2008) 3391.

[12] M. Sonmez, M. Celebi, I. Berber, Eur. J. Med. Chem. 45 (2010) 1935.

[13] S.G. Teoh, G.Y. Yeap, C.C. Loah, L.W. Foong, S.B. Teo, H.K. Fun, Polyhedron 16 (1997) 2213.

[14] H. Wada, T. Aono, K.-I. Motoda, M. Ohba, N. Matsumoto, H. Okawa, Inorg. Chim. Acta 246 (1996) 13

[15] V.V. Kogan, V.V. Lukov, Russ. J. Coord. Chem. 30 (2004) 205.

[16] H. Wada, K.-I. Motoda, M. Ohba, H. Sakiyama, N. Matsumoto, H. Okawa, Bull Chem. Soc. Jpn. 68 (1995) 1105.

[17] B.F. Hoskins, R. Robson, G.A. Williams, Inorg. Chim. Acta 16 (1976) 121.

[18] P. Guerriero, S. Tamburini, P.A. Vigato, Coord. Chem. Rev. 139 (1995) 17.

[19] M. Sarkar, R. Clerac, C. Mathoniere, N.G.R. Hearns, V. Bertolasi, D. Ray, Inorg. Chem. 49 (2010) 6575

[20] V.V. Lukov, S.I. Levchenkov, I.N. Shcherbakov, S.V. Posokhova, V.A. Kogan, Russ J. Coord. Chem. 27 (2001) 135.

[21] S. Anbu, M. Kandaswamy, P. Suthakaran, V. Murugan, B. Varghese, J. Inorg. Biochem. 103 (2009) 401.

[22] P.G. Avaji, S.A. Patil, J. Coord. Chem. 61 (2008) 2570.

[23] N. Sekine, T. Shiga, M. Ohba, H. Okawa, Bull. Chem. Soc. Jpn. 79 (2006) 881.

[24] S. Kita, H. Furutachi, H. Okawa, Inorg. Chem. 38 (1999) 4038.

[25] M. Jose Lassaletta, M. Alcarazo, R. Fernandez, Chem. Commun. (2004) 298 299.

[26] A.R. Cowley, J.R. Dilworth, P.S. Donnelly, J.M. Heslop, S.J. Ratcliffe, J. Chem. Soc. Dalton Trans. (2007) 209-217.

[27] S.F. Brian, A.J. Hannaford, P.W.G. Smith, A.R. Tatchall (Volgel's Text Book as Practical Organic Chemistry), ELBS Publishers, Singapore, 1989. pp. 395.

[28] A.I. Vogel (A Text Book of Quantitative Inorganic Analyses), 3rd ed., ELBS Longman's Green and Co. Ltd., London, 1962.

[29] C.N. Verani, E. Rentschler, T. Weyhermuller, E. Bill, P. Chaudhuri, J. Chem. Soc. Dalton Trans. (2000) 251-258.

[30] D.A. Denton, H. Suschitzky, J. Chem. Soc. (1963) 4741-4743.

[31] E.O. Offiong, S. Martelli, Farmco 49 (1994) 513.

[32] J.G. Collee, J.P. Duguid, A.G. Farser, B.D. Marmion (Eds.), Practical Medical Microbiology, Churchill Livingstone, New York, 1989.

[33] J.M. Andrews, J. Antimicrob. Chemother. 48 (2001) 5.

[34] L. Guofa, N. Chongwu, L. Bin, M. Kunyuan, Polyhedron 9 (1990) 2019. 
[35] P.G. Avaji, Eur. Med. Chem. 44 (2009) 3552.

[36] P.G. Avaji, S.A. Patil, J. Enzyme Inhib. Med. Chem. 24 (2009) 140

[37] J.E. Kovacic, Spectrochim Acta, Part A 23 (1967) 183.

[38] R. Shasidhara, T.R. Goudar, J. Indian Chem. Soc. 78 (2001) 360.

[39] C.K. Choudhary, R.K. Choudray, L.K. Mishra, J. Indian Chem. Soc. 80 (2003) 693.

[40] B.B. Mohapatra, S.K. Saraf, J. Indian Chem. Soc. 80 (2003) 696.

[41] K. Nakamoto, P.J. Mcarthy, A. Ruby, A.E. Martell, J. Am. Chem. Soc. 83 (1961) 1066

[42] G.C. Parcy, Spectrochim. Acta, Part A 31A (1976) 1287.

[43] R.J.H. Clark, Spectrochem. Acta 21 (1965) 955.

[44] A. Khan, Shahjahan, S.A. Xaidi, Indian J. Chem. 36 (1997) 153-156.

[45] Parcy, Spectrochim. Acta 31 (1976) 1287.

[46] B.N. Reddy, P.G. Avaji, P.S. Badami, S.A. Patil, J. Coord. Chem. 61 (2008) 1827

[47] D.N. Satyanarayana (Electronic Absorption Spectroscopy and Related Techniques), University Press, Hyderabad, 2001.

[48] N. Sengottuvelan, J. Mohanmani, M. Kondaswamy, Polyhedron 21 (2002) 2767.
[49] R. Kannappan, R. Mahalakshmy, T.M. Rajchdiran, R. Venkateshan, P. Sambashiva Rao, Indian Acad. Sci. Chem. Sci. 115 (2003) 1.

[50] M.C. Jain, A.K. Shrivastava, P.C. Jain, Inorg. Chem. Acta 23 (1977) 199.

[51] C.J. Balhausen, An Introduction to Ligand Field, McGraw Hill, New York, 1962.

[52] A.B.P. Lever (Inorganic Electronic Spectroscopy), Elsevier, Amsterdam, 1984. p. 23.

[53] B.N. Meyer, N.R. Ferrigni, J.E. Putnam, L.B. Jacobsen, D.E. Nichols, J.L. McLauhglin, Planta Medica 45 (1982) 31.

[54] Z.H. Chohan, A. Scozzafava, C.T. Supran, J. Enzyme Inhib. Med. Chem. 18 (2003) 259.

[55] Z.H. Chohan, H. Pervez, M.K. Khan, A. Rauf, C.T. Supuran, J. Enzyme Inhib. Med. Chem. 19 (2004) 85.

[56] Z.H. Chohan, K.M. Khan, C.T. Supuran, Appl. Organomet. Chem. 18 (2004) 305

[57] Z.H. Chohan, Synth. React. Inorg. Met-Org. Chem. 34 (2004) 833.

[58] W. Levingson, P. Mikeleus, J. Jackson, W. Kaska, in: G.N. Schranzer (Ed.) Inorganic and Nutritional Aspects of Cancer, Plenum Press, New York, 1978. 